\title{
DATA BASE FOR DISTRICT HEATING PIPE SYSTEM DESIGN
}

\author{
R. LeSSE, J. KarkheCK, H. SERRY, AND R. TeSSMER
}

August 1979

Prepared for the

OFFICE OF RESOURCE APPLICATIONS

UNITED STATES DEPARTMENT OF ENERGY

WASHINGTON, D.C. 20545

ENGINEERING DIVISION

DEPARTMENT OF ENERGY AND ENVIRONMENT

BROOKHAVEN NATIONAL LABORATORY ASSOCIATED UNIVERSITIES, INC.

UNDER CONTRACT NO. EY-76-C-02-0016 WITH THE

UNITED STATES DEPARTMENT OF ENERGY 


\section{DISCLAIMER}

This report was prepared as an account of work sponsored by an agency of the United States Government. Neither the United States Government nor any agency Thereof, nor any of their employees, makes any warranty, express or implied, or assumes any legal liability or responsibility for the accuracy, completeness, or usefulness of any information, apparatus, product, or process disclosed, or represents that its use would not infringe privately owned rights. Reference herein to any specific commercial product, process, or service by trade name, trademark, manufacturer, or otherwise does not necessarily constitute or imply its endorsement, recommendation, or favoring by the United States Government or any agency thereof. The views and opinions of authors expressed herein do not necessarily state or reflect those of the United States Government or any agency thereof. 


\section{DISCLAIMER}

Portions of this document may be illegible in electronic image products. Images are produced from the best available original document. 
BNL 51097

UC-95c

(Energy Conservation-Systems Modeling and Performance Assessment - TID 4500)

\title{
DATA BASE FOR DISTRICT HEATING PIPE SYSTEM DEESIGN
}

\author{
R. LesSe, J. KarkheCK, H. Serry, and R. Tessmer
}

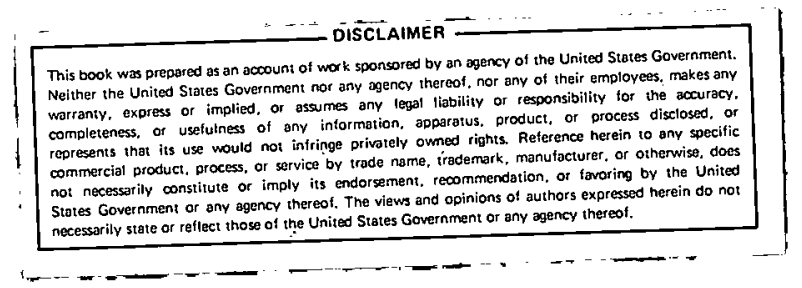

August 1979

\author{
Prepared for the \\ OFFICE OF RESOURCE APPLICATIONS \\ UNITED STATES DEPARTMENT OF ENERGY \\ WASHINGTON, D.C. 20545
}

ENGINEERING DIVISION DEPARTMENT OF ENERGY AND ENVIRONMENT 


\section{NOTICE}

This report was prepared as an account of work sponsored by the Untted Blates Lovcrnment. Nelther ille I Viviril Sitates nor the United States Department of Finergy (DOE), nor any of their employees, nor any of their contractors, subcontractors, or their employees, makes any warranty, express or implied, or assumes any legal liability or responsibility for the accuracy, completeness or usefulness of any information, apparatus, product or process disclosed, or represents that its use would not infringe privately owned rights.

Printed in the United States of America

Available from

National Technical Information Service

U.S. Department of Commerce

5285 Port Royal Road

Springfield, VA 22161

Price: Printed Cony $\$ 4.00$; Microfiche $\$ 3.00$ 


\section{Abstract}

A methodology and data base for assigning installation costs and length requirements of hot water pipes for district heat service are described. These variables are the most important elements in the cost of the distribution system. The assignment technique is applicable to any city and reflects such factors as land use intensity, congestion of present underground service lines, and local labor rates and materials procurement costs.

\section{Acknowledgements}

The patience and endurance of B. J. Mingino in preparing this document is gratefully acknowledged. In addition thanks go to numerous people in various local agencies and utilities across the country for their patience, time and candid communications; in particular we wish to thank Messers Eric L. Osterberg of Brooklyn Union Gas Co.,; Will Neumeister, Planning Department, City of Aberdeen, S. D.; Martin E. Engelhardt, Edward C. Scheader and Michael Krysko of New York City, Department of Environmental Protection. 
1. Introduction ..................... 1

2. Piping Installation cost . . . . . . . . . . . . . 1

3. Pipe Length Assessment . . . . . . . . . . . . . . 4

4. References........................ 5

FIGURES

1. Land-use intensity labor scale factor for underground-piping

installation ................... 3

2. Reference installation costs for two-way insulated piping (supply and return) at 1978 rates for labor and materials in Boston. . . . 3

3. Population per length of street, for a sample of U.S. cities, as a function of citywide population density. Dots show total population divided by total length of city-maintained streets. Solid line represents a least-mean-square fit to a straight line. . . . . . . . 3

4. Population per length of street, for the census tracts of Salt Lake City, as a function of net tract population density. Dots show tract population divided by length of city-maintained streets. in tract. Solid line represents a least-mean-square fit to a straight line . . 3 


\section{INTRODUCTION}

A growing appreciation of the conservation potential and long-term price stability demonstrated by district heating in applications abroad has prompted research into the feastbility of this technology for the United States. A number of site-specific studies ${ }^{1-3}$ and generic analysis ${ }^{4}$ indicate that district heating would be competitive now, given a high percentage of connection by potential customers.

What appears to be needed to engender a suitable institutional setting for such implementation is a systematic and comprehensive picture of the prospects for district heating throughout the United States. Studies of specific markets show that distribution piping is the dominant cost item in the district heating system. What these studies do not point out clearly is that the pipe length per square mile may vary substantially from city to city (and even within a city). Furthermore, labor rates and materials procurement costs also vary significantly, and, within any city, the cost of installing a given length of pipe can vary greatly in relation to land-use intensity and congestion of existing underground services. These factors must be incorporated as key ingredients in any assessment of the potential for district heating, but especially when a national assessment is undertaken.

Our approach to this problem is compatible with our methodology for modeling of district heating systems. ${ }^{5,6}$ This methodology comprises an analytic framework for computerized heating-demand estimation, pipe-system design, and market-penetration parametrization, which is applicable to any populated area in the country. One data base developed for this purpose characterizes the instailation cost of piping, on the basis of analysis of actual job data for installation of cold-water and gas mains in a large number of U.S. cities. Another data base, developed from measurements of street lengths within a large number of census tracts, describes the pipe-length requirements for district heat service in any tract in terms of a variety of cross-correlated tract characteristics.

In the following sections the methods employed and the contents of these data bases are described.

\section{PIPING INSTALLATION COST}

The cost of installing a unit length of hot water piping depends on many factors. Assuming installation to be done under existing streets (though in 
practice cheaper routes, for example through buildings or under sidewalks, may. be possible), the factors can be divided into two groups: those related to basic pipe installation, i.e., materials and pipe assembly, surface cut, trench dimensions, cover and resurfacing; and those involving the difficulty of working in a built-up area, which are related primarily to the labor component of the cost.

Several investigators have attempted to estimate installation costs by using professional estimators' manuals as a guide to synthesizing all possible individual cost items, but this approach is unsatisfactory for several reasons. Istimatinn nf a joh cost, because of the many subtleties involved, is not a trivial matter, and manuals do not describe the variability of labor factors for built-up areas. Application of the routines of such an approach ${ }^{7}$ to special cases yields excessively high estimates. In particular, the costs for uctual jobs on rural oil and gas pipelines or on urban water and gas lines w111 not be reproduced as spectal cases. Furthermore, differences among cities in labor rates and materials costs are significant and warrant accommodation.

Because of these shortcomings, a new approach to cost estimation was adopted. It has the advantages of incorporating the site-specific factors affecting distribution system cost and of having universal applicability across the United States. 'l'his approach is descilibed below.

A survey was taken of recent or ongoing jobs of installing cold-water or gas mains in a large number of cities. Job sites are pinpointed on maps, and land-use intensity (population density and identification of area as business or non-business district) is determined. Costs are disaggregated into materials or labor classes which are further disaggregated to yield identification of items as indispensible to the pipe 1tself or related to land-use intensity. Normalization of each cost item is made to the respective 1978 race in Boston. A large sample was taken, spanning jobs in small cities and suburbs through ongoing work in the Chicago loop, downtown Philadelphia, and Manhattan, so that the impact of land-use intensity on normalized labor cnsts rould be readily identified. Figure 1 shows the profile of labor scale factors obtained from this analysis. An area is characterized by the type of land use, central business district (CBD) or nonCBD, and the net population density. As indicated, both variables have a significant bearing on the relative cost of putting a pipe underground. 


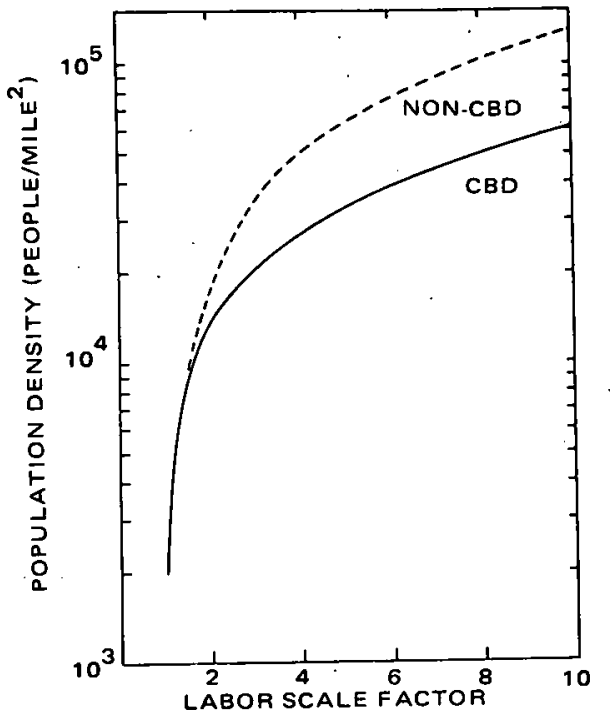

Figure 1. Land-use intensity labor scale factor for underground piping installation

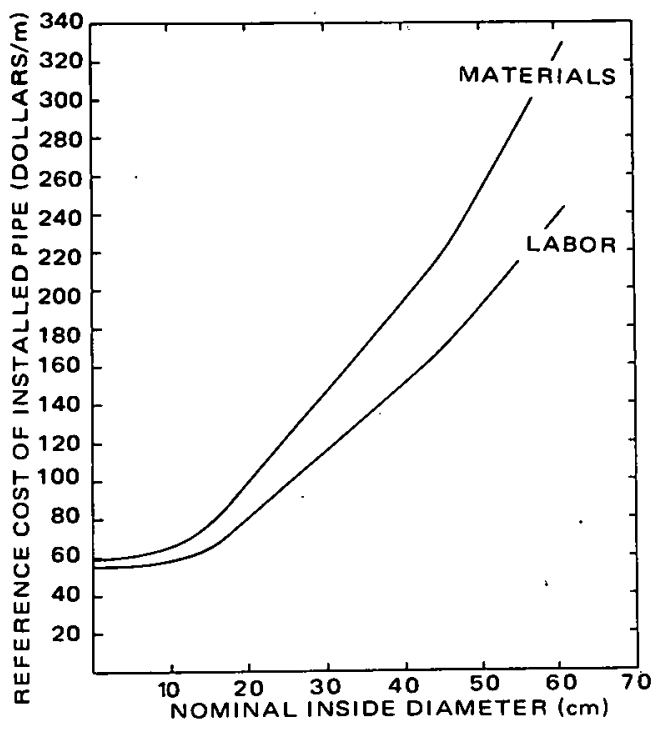

Figure 2. Reference installation costs for two-way insulated piping (supply and return) at 1978 rates for labor and materials in Boston

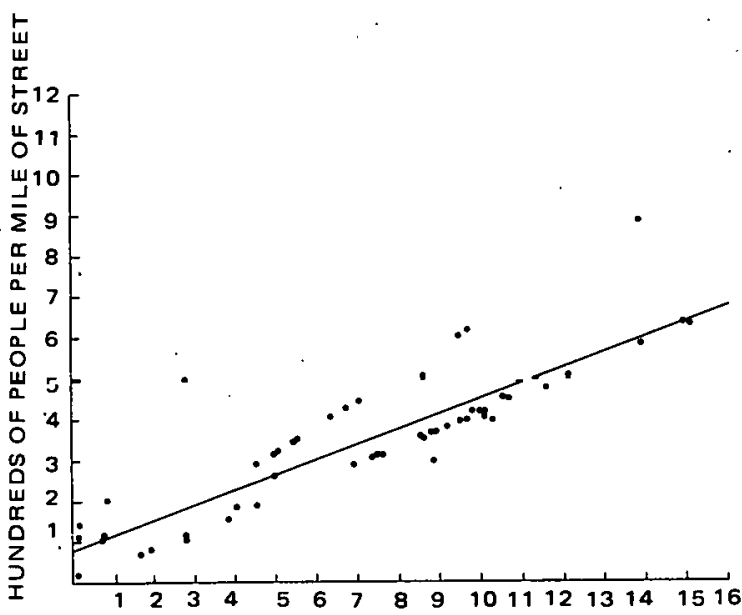

POPULATION DENSITY OF CENSUS TRACTS IN SALT LAKE CITY (THOUSANDS OF PEOPLE PER SQUARE MILE)

Figure 4. Population per length of street, for the census tracts of Sait Lake City, as a function of net tract population density. Dots show tract population divided by length of citymaintained streets in tract. Solid line represents a least-mean-square fit to a straight line 
The multiplicative labor scale factor is applied to the labor costs only. A reference piping design is made and costed, at 1978 Boston rates, by reaggregating all the relevant materials and labor items, separately, for an insulated two-pipe system (supply and return). A reference 1978 cost for each city is obtained by suitably scaling the labor and materials costs by factors for each city obtained from the Engineering News: Record data. Extension of these costs to other years is done by scaling basic items with suitable factors obtained from the same source. This reference describes the lowest cost, in a retrofit case, that would generally be encountered in installation of such a piping system. Next, the reference labor cost is multiplied by the land-use intensity labor scale factor (Figure 1) to obtain an adjusted labur cost. Addition of adjusted labor and reference material costs yields the full estimate for installation of insulated hot-water pipés.

The distinctive features of this methodology are a dependence on actual job costs and accommodation of large scale construction characteristics, the provision of detailed parameter characterization, and the ability to yield actual job costs for water and gas mains as special cases. Moreover, the methodology is applicable to any piping technology.

Clearly the assumed technology has a direct bearing on the reference cost. Conventional European technology employs welded and insulated steel pipe laid in drainage-equipped concrete ducts. ${ }^{9}$ This expensive procedure is used to prevent corrosion and keep the insulation dry. For reasons discussed else- . where, ${ }^{10}$ our reference design consists of direct-buried mechanica1-joint ductile iron pipe that is insulated, coated, and wrapped with a waterproofing jacket. This approach is less cost1y than the former yet more costly than units made from non-corroding ${ }^{1}$ or prefabricated material. ${ }^{11}$ Figure 2 shows our reterence costs, at Boston rates. They would be lower in rural areas because of omission of street surface work and easier working conditions.

\section{PIPE LENGTH ASSIGNMENT}

Assuming diotrict heating pipes to he installed in existing streets, there remains the task of determining the length of pipe required to serve a given section of a city. Pipe system cost has a more pronounced dependence on the length than on the diameter of the pipe.

This task is handled in two steps. The first comprises measurement of street lengths in a large sample of census tracts for a cross section of U.S. cities. These are computerized and correlated with census tract characteristics 
including population density, building density, and land-use type. Next, it is assumed that district heat service would require a penetration of pipes in streets comparable to that covered by cold-water service. wherever city water service is provided. Thus, a street-penetration percentage profile is established by the study of water-main maps. As a control, the total length of citymaintained streets was compiled for each city.

To illustrate our findings, Figures 3 : and 4 show the number of people per mile of street versus population density for a large sample of cities and for the census tracts in Salt Lake City. These curyes suggest that implementation of district heating is most efficacious in sections of high population density (or high demand density), having a large number of customers per mile of pipe. However, the excess labor costs (Figure 1) offset this advantage to some extent.

To illustrate further, street densities (i.e., length of street per square mile) were found ranging from 15 to greater than $35 \mathrm{miles} / \mathrm{mile}^{2}$, with a large percentage of tracts having 20 to $28 \mathrm{miles} / \mathrm{mile}^{2}$. Pipe penetration is virtually $100 \%$ in fully utilized tracts but can be as 1 ow as $80 \%$ in newly developed tracts. Thus it is clear that pipe length requirements vary by a factor of two or more from suburban areas through central city districts.

\section{REFERENCES}

1. Karkheck, J., Beardsworth, E., and Powell, J. R., The Technical and Economic Feasibility of U.S. District Heating Systems Using Waste Heat From Fusion Reactors, BNL 50516, Feb. 1976.

2. Santini, D., Davis, A., and Marder, S., Costs of Urban Area Retrofit to District Heating and Cooling Systems, North Central Cities, ANL/ICES-TM-9, 1978 .

3. Minneapolis-St. Paul district heating study, executive summary, Presented at District Heating/Cogeneration Symp., Minneapolis, April 1979.

4. Karkheck, J. and Powell, J. R., The application of district heating systems to U.S. urban areas, in Efficient Comfort Conditioning: The heating and Cooling of Buildings, W.G. Berl and W. R. Powell, Editors, AAAS Selected Eymposium 27, 1979 .

5. Karkheck, J. and Tessmer. R. G., Methodology for Modeling Geothermal District Heating for Residential Markets, BNL 50905, Aug. 1978.

6. Karkheck, J. and Tessmer, R. G., Public data sources and modeling of district heating in the United States, Proceedings of the Energy Symposia, Montreux, Switzerland, June 1979. 
7. Oliker, I., Edelman, R. A., and DeVito, L.,, Urban Area District Energy System Study, Burns and Roe, Oradel1, N. J., Oct. 1977.

8. Engineering News Record, Vo1. 201, No. 1, p.44; No. 2, p.31; No. 5, p.32 (1978).

9. Larsson, K., District heating: Swedish experience of an energy efficient concept, Prejsented at 1977 Swedish Seminar on the Approach to Current and Future Energy Issues.

10. Serry, H., Underground Piping Systems for District Heating, BNL 25494 , Sep. 1978 .

11. Olszewski, M., Preliminary Investigation of the Thermal Energy Grid Concept, ORNL/TM-5768, Oct. 1977 . 